\title{
医療機関における医科学サポート活動 〜予防教育の取り組み〜
}

\author{
緒 方 隆 裕 \\ (久恒病院 原ベースボール医学研究所)
}

スポーツ医科学サポート活動として, 当院に特長 的な「メディカルチェック活動」と「ミニキャンプ 治療」について紹介させて頂きます。当院は福岡 県粕屋郡志免町にあり, 福岡空港から車で約15分, JR博多駅から車で約30分の場所にあります。主な 診療科には整形外科・外科・生活習慣病外来があ り，整形外科の手術は肩関節（野球肩，反復性脱 臼，腱板断裂等の鏡視下手術）と各関節の手術（骨 折, 脱臼, 勒带, 半月板等) の症例が多く, 全国よ りスポーツ障害に悩むアスリートが数多く訪れて

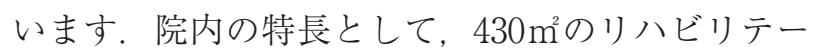
ション室があり, 理学療法士 27 名・作業療法士 2 名 がリハビリテーション治療を実施し, 病院の横には ブルペンが併設されており, 治療に訪れた野球選手 が調整のために使用しております.

「メディカルチェック活動」について

当院では，スポーツ障害の治療だけでなく，ス ポーツ障害の予防を目的にスポーツ選手を対象にメ ディカルチェックを実施しています。

プロ野球選手は昨年度約50名が来院され, 当院に おいてメディカルチェックを受けています。内容 は, 診察, 検査 $(\mathrm{MRI} \cdot \mathrm{X}$ 線・超音波), 栄養アン ケート調査，肩関節・股関節を中心とした全身の チェック, リハビリ治療, 選手各個人へのトレーニ ング指導, チームトレーナーへの医学情報のフィー ドバック等を行っています。

アマチュアスポーツ選手に対しては, チーム単位 でメディカルチェックを実施しており，昨年度は, 大学硬式野球部・大学バドミントン部・高校硬式野 球部・高校女子ソフトボール部・中学女子ソフト ボール部・中学女子バレーボール部に対してメディ カルチェック活動を実施しています。内容は, 医 師・理学療法士・管理栄養士による勉強会, リハビ リ・栄養アンケート調查, 肩関節・股関節を中心と した全身のチェック，筋力訓練・ストレッチ指導， その後個人・チームへの身体状況のフィードバック 等を行っています.

チェックの項目としては, 股関節可動域・肩関節
11項目テスト・肘関節可動域・全身関節弛緩性・X 線（下方ストレス撮影・ゼロポジション撮影）・超音 波 (棘下筋厚・収縮率) 等を実施しています。また, 経年的・定期的に実施する事によって，コンディ ション・パフォーマンスの維持, そして選手寿命を 延ばす事に繋がるのではないかと考えています。

\section{「ミニキャンプ治療」について}

約 1 週間の短期入院によるリハビリテーション治 療の事で, 肩・肘関節に障害をもつ高校・大学・社 会人のスポーツ選手を対象に行っています。この 1 週間の間に集中的に治療するとともに，肩・肘関節 の構造やトレーニング法を学習し, 退院後自ら障害 への対処が出来るように，再発を予防できるよう に指導・教育を行っている。内容は, 診察, 検査 $(\mathrm{MRI} \cdot \mathrm{X}$ 線)，肩関節・股関節を中心とした全身の チェック, 理学療法士・管理栄養士による勉強会, 障害部位への脊髄反射を利用したリハビリ治療，イ ンナーマッスル・アウターマッスルのバランス調整, インナーマッスル筋力トレーニング，運動連鎖に基 ついた動作指導，ストレッチ指導等を行っている.

1 週間のスケジュールとしては, 前半はインナー マッスル訓練・ストレッチを重点的に指導し，イン ナーマッスルの状態が整った状態になってからアウ ターマッスル訓練を開始し, 最終的には競技に適し た複合運動へと続けていきます。リハビリ治療の一 例としては，棘下筋の状態を触診によりチェック し, 下垂位での内外旋運動時に収縮・弛緩を繰り返 しているかをチェックします。それから下垂位で屈 曲・伸展 ·内転・外転方向への抵抗運動をすること によって, インナー・アウターの筋を段階的に刺激 し, 徐々に強化・トレーニングしていきます。ま た，ストレッチの一例としては，肩関節外旋筋の筋 疲労・持続的な筋緊張を解くために, 拮抗筋である 内旋筋に抵抗運動をすることによって，外旋筋の緊 張状態を解いてから外旋筋のストレッチを実施して いる。この方法はストレッチ効果もあり，筋組織へ の負担も少ないと考えています。 